\title{
EVALUATION FOR THE UTILITY OF THE POST-AURICULAR RESPONSE EVOKED BY ACOUSTIC STIMULI IN OBJECTIVE AUDIOMETRY.
}

\author{
TŌRU ŌHASHI, M.D. \&JUNICHI ŌTSUKI, M.D.
}

\author{
Department of Otolaryngology, Shizuoka Red Cross Hospital, Shizuoka.
}

\begin{abstract}
The present study was mainly concerned with significane of the clinical use of post-auricular myogenic evoked response as the objective audiometry. The response to acoustic stimuli of clicks and pure tone bursts was tecorded from the skin surface behind the pinna by means of the average response computer. In addition, the cochlear nerve action potential (AP) was recorded from the promontrium using a transtympanic electrode, with the post-auricular response simultaneously. Twentytwo subjects with normal hearing and four patients with various types of hearing loss were tested. The following results were obtained.

1) The post-auricular response showed a biphasic waveform, that is an initial negative peak followed by a positive one. The amplitude of the response was varied to the high extent across subjects, but the latency of it was relatively stable.

2) The thresholds of the response to clicks in normal hearing subjects were as low as the values of the subjective thresholds. The response to pure tone bursts showed higher thresholds than that to cliks.

3) The response failed to be recorded in 5 subjects with normal hearing.

4) The response could be recorded not only from subjects in awake but also from subjects in sedation.

5) The threshold of the post-auricular response highly correlated with that of the AP in patients with various type of hearing loss.

6) It can be said that the post-auricular response might serve as a very useful index for object ive audiometry.
\end{abstract}

A78-0826. 23022

音響刺激性後耳介反応の他覚的聴力測定への応用についての検討

静岡赤十字病院耳鼻咽喉科
大 橋 微 $\cdot$ 大 築 潡 -

緒言

近年, コンピュータの加算平均法を応用することによ り頭皮上の種々の部位より各種の音響性誘発反応を記録 できることが分かつてきた。 このうち現在まで，他覚的 聴力検查の目的で一般に広く流布されている反応は, 頭 頂部より誘尊される長い潜時（約 $50 \mathrm{msec} \sim 500 \mathrm{msec}$ ) ○
大腷性誘発電位である゙）．しかし fast evoked response 又は sonomotor response と呼ばれる短い潜時（約10 $\mathrm{msec} \sim 50 \mathrm{msec}$ ）の笳源性誘発反応も他覚的聴力測定に 利用できることが報告されている24)6)83 この筋源性反 応 (myogenic potential) の解剖学的経路および生理機 構については諸説がある(1)(3)11) 現在までの知見による 
と，この反応は主として頭頸部の筋群の筋毉張，いわぬ る muscle tonus の影響を非常に受けることが知られて いる. そのため, この反応の城值や振幅比較的変動が 大きく，臨床的応用には反応の再現性という点で問題が あつた，筇源性誘発反応は，誘導部位によつて，(1)後頭 部より誘導される Inion response (Bickford, 等1)，1964 Cody 等3)，1964) (2)後耳介部，乳突部から誘遵される post-auricular response (Kiang 等11), 1963. Jacobson 等10), 1964. Yoshie 等20), 1969. Douek 等6), 1973.) (3) 頭頂部より誘導される short-latency vertex and parietal response (Mast ${ }^{18)}$, 1965. Goldstein ${ }^{7)}$, 1965. Goldstein ${ }^{8)}$, 等 ${ }^{8)}$ ，1967.) の三種類に分類される。(1)の反応は，前庭 経由筋源性反応 (Vestibulo-myogenic) とも考えられ， 前庭の機能によつて左右され反応域值も高いと云われて いる，(2)の反応は，蛊牛経由筋源性反応（Ccchleo-myogenic）と考えられ比較的反応域値も低く他覚的 聴力測 定の指標として三つの反応のうちでは最も有望な指標と 考えられるものである.(3)の反応は，前二者にくらべて 末解決の点が多く，その存在の有無も問題があるので現 状では臨床的に応用するには不適であると考えられる。 われわれは，特に後耳介反応が聴覚検査の指標に最もす ぐれた点であることに着目し，本反応を指標とした他覚 的聴力測定の確立を目的として本研究を行つた，検討齐 行つた主な項目を列記すると(1)正常耳での本反応の入出 力関係 (反応潜時, 振幅対刺激強度との関 係) (2) 反忘 域值(3)刺激頻度と反応潜時, 振幅との関係(4) 短音刺激 (pure tone burst) の立ち上り時間（rise time）と反応 振幅上の関係(5)各種難聴耳での本反応上螖牛神経活動雷 位との反応城值の比較，の五項目についてだある。

$$
\text { 方法 }
$$

測定装置のブロック・ダイアグラムは図一1に示す 関電極は㨫波用ディスク電極を使用して，後耳介部の耳 介附着中央部(後耳介筋に対応子る部位)の皮虞表面に電 極ペーストで接着固定した，不関電極は，ディスク電極 を利用し，耳梁に電極ペーストで接着固定した．接地電 極は，ディスク電極を前額中央部に置いた，音響刺激と しては，クリック执よび短音（pure tone bursts）壳開 故系で与えた，クリックは，0.07 $\mathrm{msec} の$ 矩形波を原信 号として,出力増幅器を通してスピーカより与えた.クリ ックの主要ピーク成分の波形は，4000Hz の半波長波形 に最も類似したものであつた.短音活,純音発振器から発 生する純音 $(500 \mathrm{~Hz}, 1000 \mathrm{~Hz}, 4000 \mathrm{~Hz}, 6000 \mathrm{~Hz})$ を電子 スイッチで目的の立ち上り時間 (rise time) と持続時間 を持つた短音（pure tone bursts）に形成して出力增幅 器を通しスピーカを経て与えた。特別な場合（刺激填度 亡反応の相関）を除いて，刺激覑度は，クリック，短音 ともに1秒に5〜8回の割合で与えた，なお，短音の場 合，特別な場合（立ち上り時間と反応の相関）を除いて は立ち上り時間 $2.5 \mathrm{msec}$ ，持続時閒 $30 \mathrm{msec} \sim 50 \mathrm{msec}$ を 使用した。

刺激音の強度は，德力正常青年（男女10名）の平均自 覚域值を $\mathrm{OdB}$ として表現し，この強度を本研究では便 宜上, 記号的に, dB HL として表現した。なお，スピ 一カは，雨耳を底辺とする二等辺三角形の頂点 (スピー カと両外耳道口の距離は，約 $50 \mathrm{~cm}$ ) に置いた。被検者 は，シールドされた測定室内のベッドに仰臥位にさせ， 頭部を一定の位置に保つよら指示した，特に重要なの は，頭钼部の筋肉群の緊張状態をできるだけ一定に保つ ことである. 反応のデータ処理は, 前置増幅器(周波数 带; $4 \mathrm{~Hz} \sim 10 \mathrm{KHz}$ ) で增幅(約 500 倍) した後, デジタル 加算器 (日本光電 ATAC 201) で解析時間 $50 \mathrm{msec}$ 利用して 200 回加算した. 加算処理の結果は，XYレコ 一ダでアナログ波形として記録した.

被検者は，3〜30才までの聴力正常者22名，および4 名の各種難聴患者であつた．5才以下の子供には，原則 としてトリクロリール・シロップ $1 \mathrm{cc} / \mathrm{kg}$ を服用させ睡 眠させて記録した，比較のため, 鼓室内裙導法 ${ }^{22233}$ によ って蜡牛神経活動電位（以下 AP と略す）記録した。

\section{成}

\section{縤}

I 、正常耳の後耳年応の基本的電気生理学的特性； 正常聴力者 22 名中 5 名（約 $22.5 \%$ ）は，いかなる努力を 払つても本反応を記録することができなかつた，明確な 原因を解明することはできなかつた，以下の成績は，反 応の記録できた17名のデータに基づいている。

i) 反応の久出力関係（反応の潜時，振幅 対刺激強 度)、図一2 は後耳介反応の典型的波形である，最初の 陰性波，つぶいて陽性波からなる2相性の波形である。 道常, $60 \mathrm{~dB} \mathrm{HL} \sim 10 \mathrm{~dB} \mathrm{HL}$ の束激強度では，陰性波の ピーク潜時は，12msec〜 $17 \mathrm{msec}$, 陽性波のピーク潜時は $18 \mathrm{msec} \sim 22 \mathrm{msec}$ である。図一 3 は，クリックによる反 灾について，刺激強度の变化による反応波形の変化を示 したものである、この成纉はトリクロリールシロップで 睡眠させた 5 才女子から記録したものである。なお，本 被険者について賞醒時に記録された本反応の波形と域值 は，全く睡眠時（図一3）のそれと同様であることが判 明した。このことは本被検者のみならず，他の3名の被 


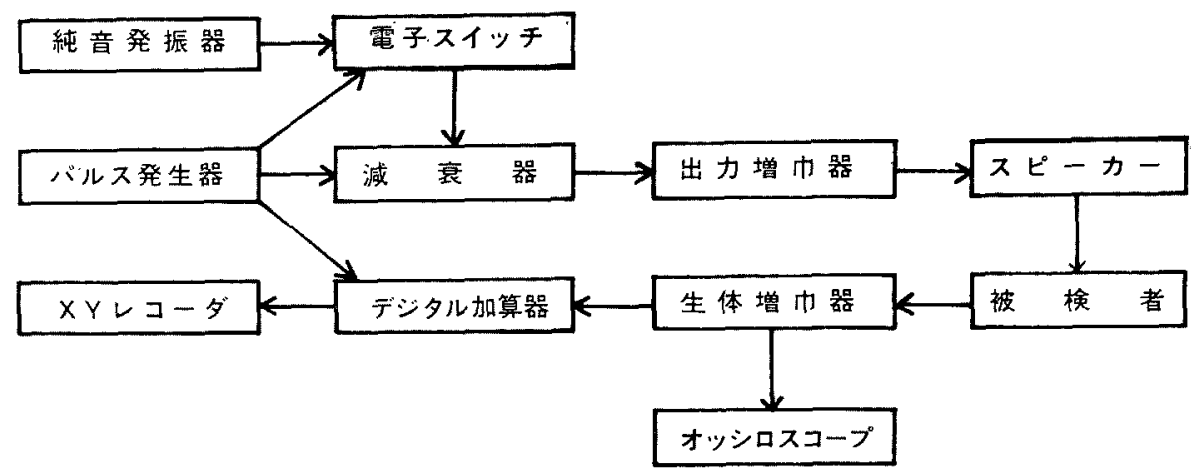

図一1＼cjkstart測定装置のブロックダイアグラム

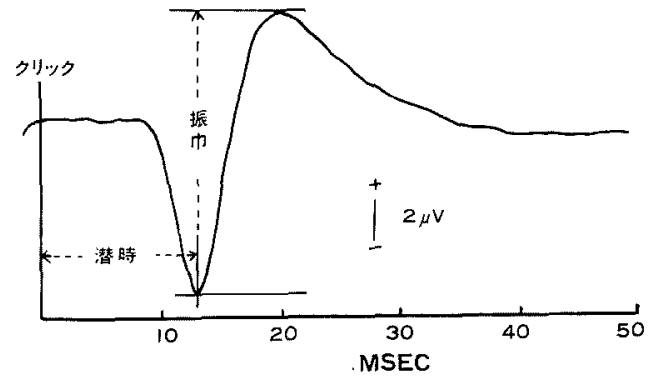

図一2 後耳介反応の典型的波形

刺 激 音:クリック

刺 激 強 度: $40 \mathrm{~dB} \mathrm{HL}$

刺激 頻度: 4 回/秒

加算平均回数：200回

被 検 者：25才，聴力正常男子

検者についても比較を行つたが，全く同様の成績が得ら れた。さらにケタラール麻酔下でも覚醒時と同様の成績 が得られた。

反応振幅梳，刺激強度の增大とともに大きくなり潜時 は短縮する。図一 4 は，クリック刺激性反心夋振幅と潜 時の入出力曲線である．潜時の測定は，刺激音が鼓膜に 達した時点（コンデンサーマイク法によつて推定）を基 準点として、ここからら陰性波のピークまでの時間を潜時 と決めた，反応振幅としては，陰性波のピークから陽性 波のピーク岳での高さ (peak-to-peak amlitude) を使用 した（図一 2 参照）。図一 4 加ら個々の反応振幅のばら つきは，非常に大きいことが示されている。

反応振幅の著しいばらつきは，被検者の筋群（主に後 耳介筋) の緊張状態 (muscle tonus) の相違と, 電極装 着位置の相違に起因するのではないかと思すれる。図一 4 に示された入出力曲線のデータからは一定の傾向を見 いだすことはできない一方, 潜時の場合は,振幅に比べ

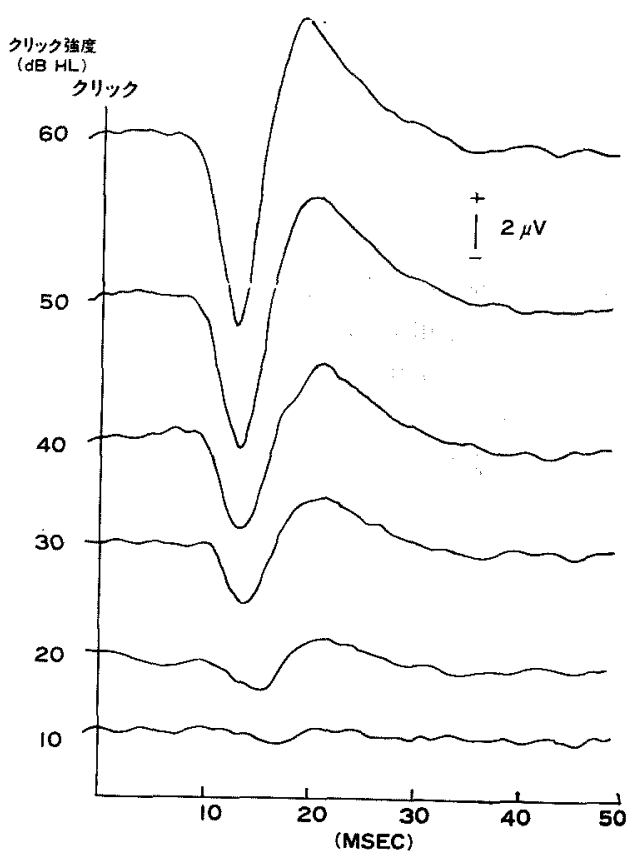

図一 3 刺激強度の変化による反浨波形の変化 被検者：聴力正常の5才女子 トリクロリー ルシロップにより睡眠させた。

刺激音：クリック 加算平均回数：200回

て個体差が少ないことは注目される。図一5，図一6。 図一7. 図一8 は, 短音刺激時 $(500 \mathrm{~Hz}, 1000 \mathrm{~Hz}, 4000$ $\mathrm{Hz}, 6000 \mathrm{~Hz}$ の 4 種類の pure tone bursts) の振幅と潜 時の大出力曲線である. 短音刺激による反応がクリック 刺激によるそれと異なる点を列挙すれば，(1)短音刺激の 場合はクリック刺激よりも本反応は出現しにくいすすな わち，短音刺激性反応（立ち上り時間 $2.5 \mathrm{msec}$ ，持続時 閒 $30 \sim 50 \mathrm{msec}$ ) の域值は，クリック刺激性反応のそれ 


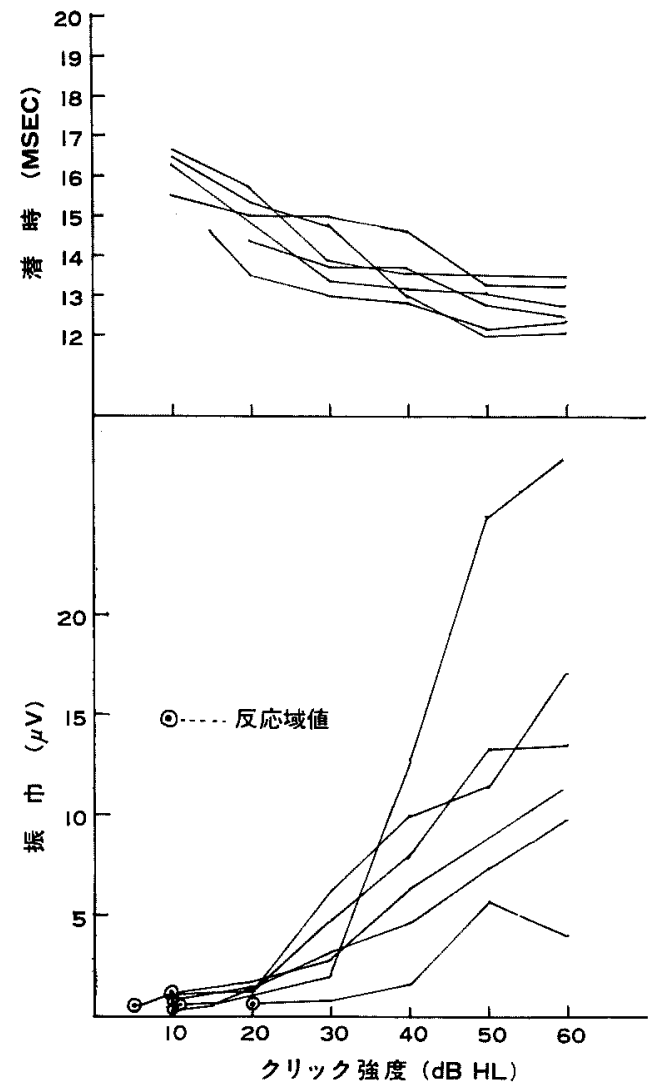

図一4クリック刺激時の本反忘の振幅及 び潜時の入出力曲線

6 名の聴力正常被検者加らのデータを示し てある。

振幅及び潜時の測定基準については本文を 参照されたい.

○印は反応の最少可視的検出刺激強度（反 応城值）を表わす

より高く反応振幅も小さい. (2)短音刺激時の反応潜 時 は，クリック刺激時のそれに比べて個体差によるばらつ きが著しい。(3)短音刺激時の反応潜時は，クリック刺激 時のそれに比べて刺激強度の増大とともに急激に増大寸 る傾向（潜時曲線の勾配が，より大きい）がある。な お， 反応振幅曲線については，短音刺激時とクリック刺 激時の閒には著明な相違は認められない。

ii）反応域值について，反応域値としては，加算波形 の最少可視的検出刺激強度 (dB HL) を用いた。これは 通常 Visual detection Level (VDL) ともいわれるもの である。

(1) クリック刺激時と短音刺激時の反応域值の相違.

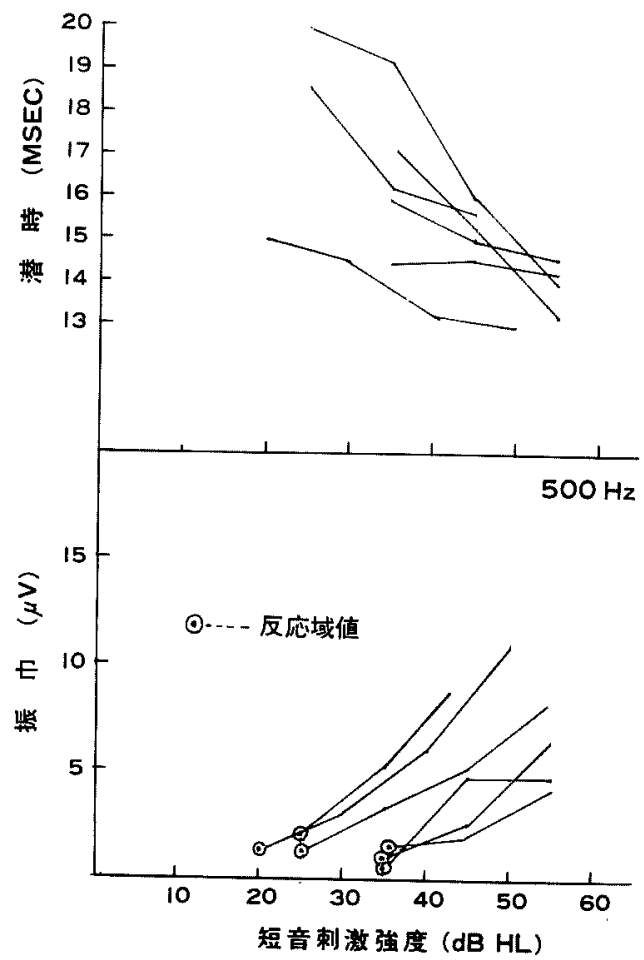

図一5 短音刺激時の本反応の振幅及じ潜 時の入出曲線

6 名の聴力正常被検者からのデータを示す 刺激周波数: $500 \mathrm{~Hz}$

○印は反応域值を表わす

反応振幅の入出力曲線 (図一 -4 , 図-5, 図一 6 , 図-7 図一8）のデータの一般的傾向として，クリック刺激時 の方が短音刺激時よりも反応域值は低いクリック刺激 の場合，反応域值は平均して約 $11 \mathrm{~dB} \mathrm{HL} \mathrm{(5 \textrm {dB } \mathrm { HL } \sim ~}$ $20 \mathrm{~dB} \mathrm{HL})$, 短音刺激の場合, 刺激周波数 $6000 \mathrm{~Hz}$ で平 均して $21 \mathrm{~dB} \mathrm{HL}(15 \mathrm{~dB} \mathrm{HL} \sim 30 \mathrm{~dB} \mathrm{HL})$, 刺激周波数 $4000 \mathrm{~Hz}$ で平均して約 $21 \mathrm{~dB} \mathrm{HL}(15 \mathrm{~dB} \mathrm{HL} \sim 25 \mathrm{~dB} \mathrm{HL}$ ), 刺 激周波数 $1000 \mathrm{~Hz}$ で平均して䄪 $34 \mathrm{~dB} \mathrm{HL}(20 \mathrm{~dB} \mathrm{HL} \sim$ $45 \mathrm{~dB} \mathrm{HL}$ ), 刺激周波数 $500 \mathrm{~Hz}$ で平均して約 $29 \mathrm{~dB} \mathrm{HL}$ (20dB HL 35dB HL) であつた.

（2）麻酔の域値におよぼす影響，麻酔が本反応の域值 におよぼす影響を知るためにケタラール麻础下のクリッ ク刺激性反応の域值を 3 名の被検者について検討した。 図一9はその奏験のデータの一部である。被検者は 4 才 8 力月男子, ケタラール麻酔下, クリック刺激時の後耳 介反店と AP の二反応を示している。ケタラール麻酔下 でも，後耳介反応の，域梿のみならず波形も覚醒時又は 


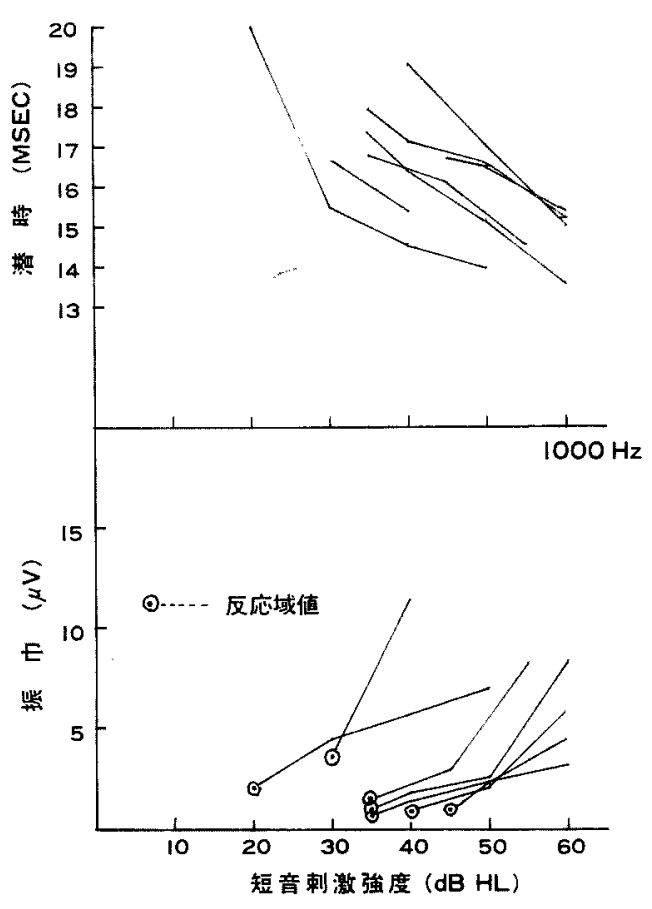

図一6 短音刺激時の本反応の振幅及び潜 時の入出力曲線

7 名の聴力正常被検者からのデータを示す 刺激周波数 : $1000 \mathrm{~Hz}$

○印は反応城值を表わす

トリクロリールシロップ睡眠時のそれとほとんど同じで あることが分つた。

(3) 後耳介反忘と AP の域值の比較. 最後に AP の 域值と後耳介反応の域值の比較を 4 名の正常被検者につ いて行つた，刺激にはクリックを用いた，図一-9のよう な反応波形が得られる。結果として両者の域值差は平均 して約 $5 \mathrm{~dB}$ でありほとんどー致するといつてもよいと 思われた。

iii）刺激頻度と反応潜時，振幅との関係，図一10法， クリック刺激頻度を 4 回/秒 30回/秒まで増加した時の 反応波形の変化を示したものである. 反応振幅は, 刺激 頻度の増加とともに娍少するが，潜時はほとんど変化を 受けないことが示されている，図一11は，振幅と潜時を 刺激頻度の函数として表現した曲線（頻度曲線）で男 る. 3 回/秒〜 8 回/秒の籁囲では, 振幅はほとんど変化 しないが，20回/秒になると，振幅は約 $1 / 2$ に減少する。

一方, 潜時は, 頻度の変化によつてもほとんど影響を受 けないことが示されている。

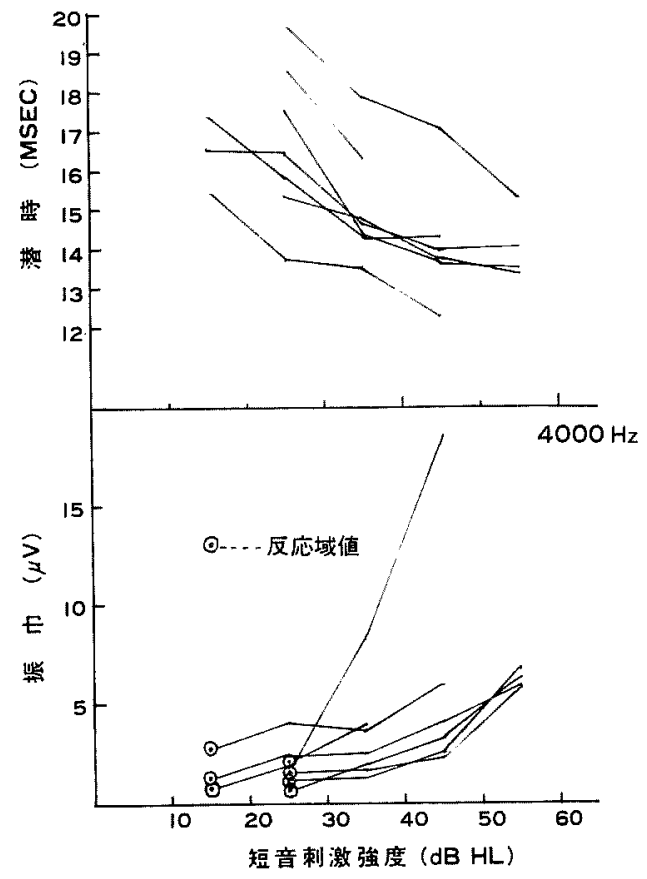

図一７短音刺激時の本反応の振幅及び潜 時の入出力曲線

7 名の德力正常被検者からのデータを示す 刺激周波数 : $4000 \mathrm{~Hz}$

○印は反応域值を表わす

iv) 立ち上り時䦓 (rise time) と反応振幅との関係.

図-12 は, 刺激周波数 $4000 \mathrm{~Hz}$, 刺激強度 $35 \mathrm{~dB} \mathrm{HL} の$ 短音の立ち上り時間を $1 \mathrm{msec}$ から $50 \mathrm{msec}$ まで変化さ せた時の振幅の変化を示す 立ち上り時間が $5 \mathrm{msec} よ り$ 長くなると，振幅は著明な減少を示す 立ち上り時間が $50 \mathrm{msec}$ の非常に延長した短音でも本反応は検出できる が，立ち上り時間 $1 \mathrm{msec}$ の場合に比心゙，反応振幅は著 明に減少 $($ 約 $1 / 4)$ していることが分かる.

II 後耳介反応の臨床的検討；われわれは，これまで 比較的多数の難聴症例について, 後耳介反応とAP の同 時記録を行つてきた ${ }^{14)}$ その詳細の検討については，他 に報告する予定であるのでここでは，本反応の臨床的応 用の可能性を紹介する意味で代表的 4 症例（図一13，図 -14, 図一15，図一16）についてのみの成績を報告す る. 第 1 症例（図一13）は，右顔面神経麻瘏を伴つた， 脳外科的腫瘍摘出手術術後の㯖神経腫瘍症例である.両 耳とも，柽度の難聴を認める．健側では明らかに後耳介 反応を記録できた，一方患側では全く後耳介反応を記録 できなかつた。しかし APは患側（右側）からも記録で 


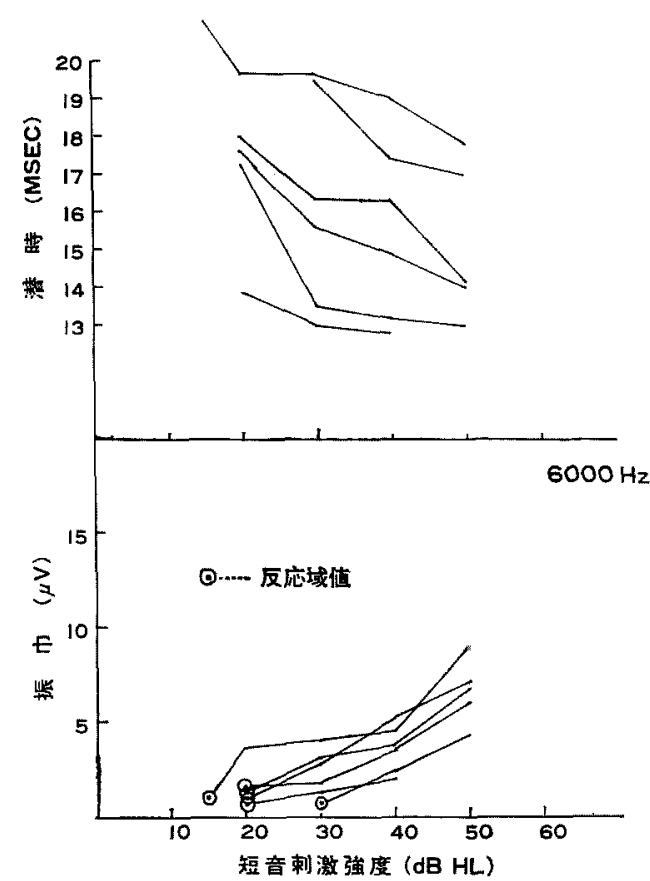

図一8 短音刺激時の本反応の振愊及び潜 時の入出力曲線

6名の聴力正常被検者からのデータを示す 刺激周波数 : $6000 \mathrm{~Hz}$

○印は反応域值を表わす
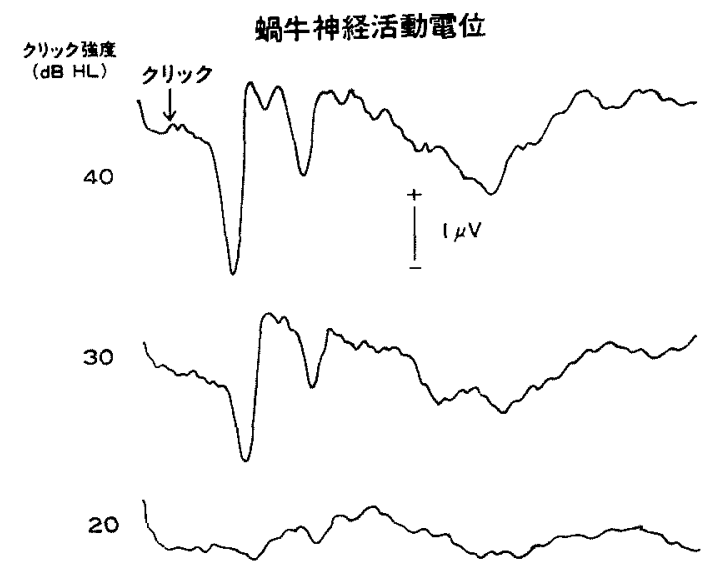

10

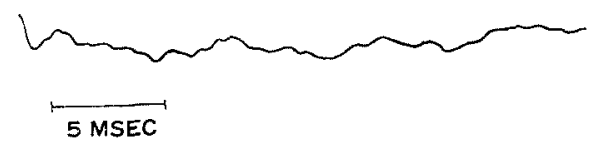

きた。したがつてこの例は蝸牛機能がほぼ正常であるに もかかわらず(AP のデータから推測) 後耳介反応が出 現しなかった症例である。顔面神経麻溥のために後耳介 反応が出現しなかつをものと推測される。われわれは， 高度のベル氏麻㾝患者からは本反応が記録できないこと を確認しているが，やはり顔面神経は後耳介反応と密接 な関倸にあることが推定される。第 2 症例 (図-14) は, 高音急壁型の内耳性難聴症例である。この症例のよ らに高音急丞型の内耳性難聴では, AP の反応域值は上 昇するが，後耳介反応の反応域值は $\mathrm{AP}$ 程には上昇しな 、場合が多い，例えばこの症例では後耳介反空の域值は AP のそれより低いこの症例から，オージオグラムの パターンが，後耳介反応と APの，域值におよ汸す影響 では, 二者の間に若干の相違のあることが推測される. この点㤝，域値測定の臨床にて注意す心゙ことである。 第3 症例（図一15）は，低音下降型の感音性難聴であ る。後耳介反応の域值は，35dB HL， AP のそれは 30 dB HL である.すなわち両者はほと儿ど同じと考えら れる。このように低音下降型の場合は, 後耳介反応々 AP の反応域値は, クリック刺激の場合は大体一致する ことが多、第 4 症例（図一16）は，高度の混合性難聴 症例である。後耳介反応の反応域值は $35 \mathrm{~dB} \mathrm{HL}, \mathrm{AP}$ のそれは $40 \mathrm{~dB} \mathrm{HL}$ である.なお，この症例では， AP の潜時は，同程度の聴力損失を持つた緇粋な内耳性難聴

\section{後耳介反応}
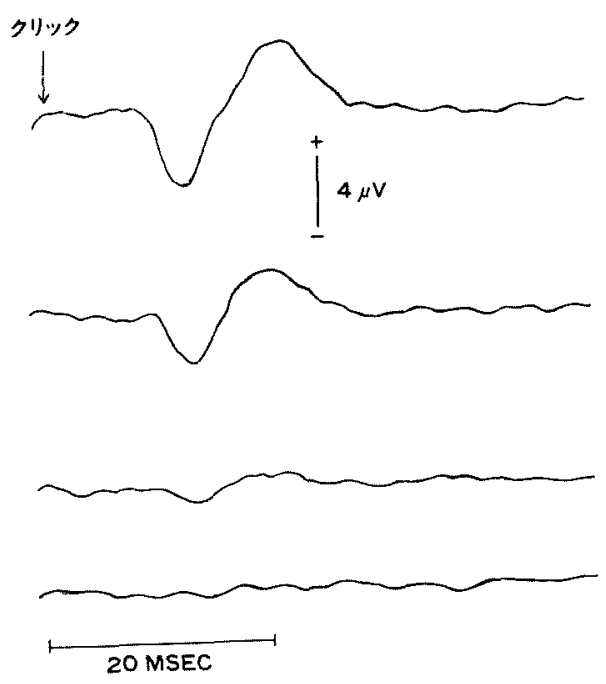

図一9聴力正常耳での後耳介反応と蛤牛神経活動能位との比較 被検者：4才8力月男子。ケタラール麻酔を施した。 音刺激：クリック

加算平均回数：後耳介反応の場合は200回 AP の場合は400回 


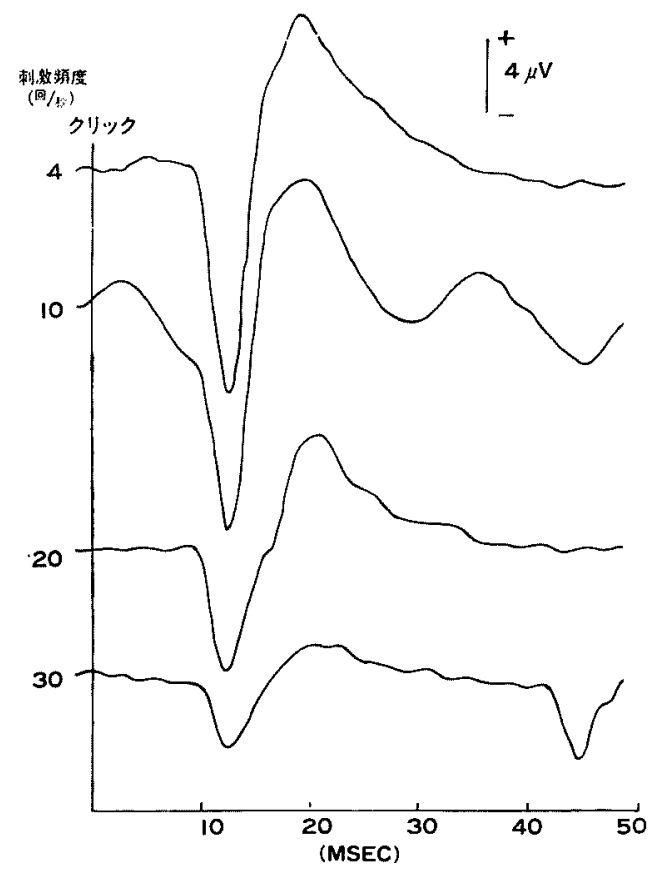

図一10 クリック刺激頻度の変化による反 応波形の変化

被検者：26才，聴力正常女子

加算平均回数. 200 回

クリック強度 : $35 \mathrm{~dB} \mathrm{HL}$

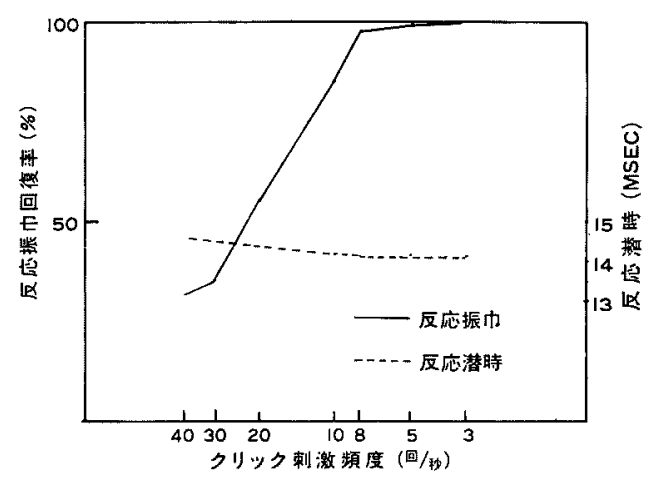

図一-11 本反応の振幅と潜時の刺激頻度曲線 反応振幅回復率 (\%) は, クリック刺 激頻度 3 回/秒に対する振幅を100として 表現した。 6 名の聴力正常被検者加らの 平均を示した。

クリック強度：35dB HL

クリック刺激頻度は対数尺度で表わして ある。

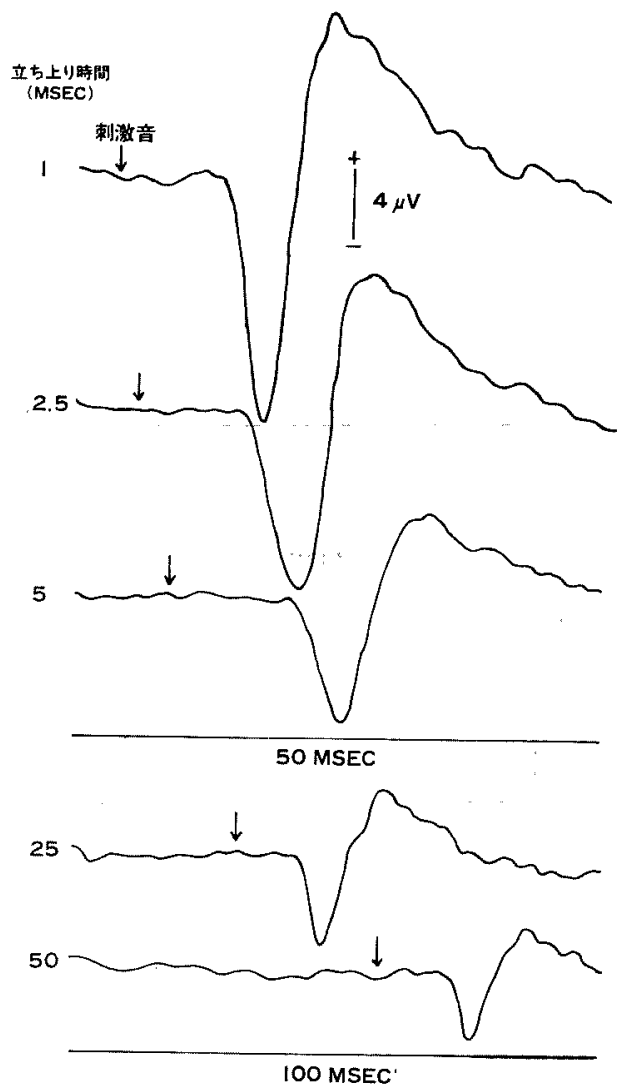

図一I2 刺激音の立ち上り時間(rise time) の変化による反応振幅の変化

被検者：24才，聴力正常女子 刺激周波数: $4000 \mathrm{~Hz}$ 刺激強度 : $35 \mathrm{~dB} \mathrm{HL}$ 加算平均回数：200回

耳のそれに比し延長している.この事実は，この難聴 は，純粋な感音性難聴のみならず伝音性難聴の混在を示 すものといえる(L一曲線部分の一部残存 $\left.{ }^{15}\right)$. 反応域值 だけを見れば，雨反応はほとんど同じ城值を持っと考え られる，以上の症例の検討加ら分かるよらに，クリック 刺激時においては，後耳介反応は，特殊な聴力像を示す 難聴症例を除いては（例えば第 2 症例の高音急壁型の如 き場合)，APと反応城值はほとんど一致すると考えられ る. 更に後耳介反応も AP と同椂，難聴耳では，その聴 力損失の程度に応してて, 反応城值は上昇するのが分か 万.

考按

他覚的聴力測定の方法でこれまで最も普及している方 


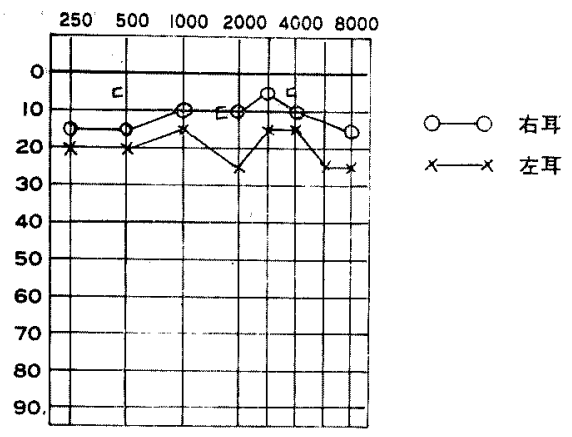

後耳介応

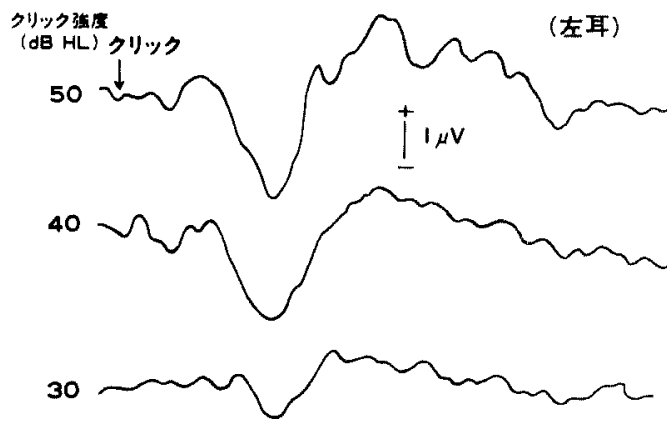

(右耳)

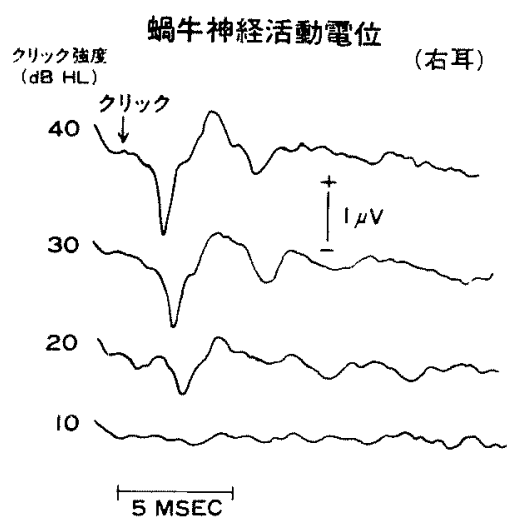

60

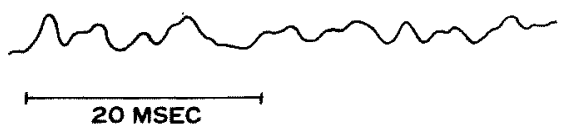

图一13 右側顔面神経麻疩伴亏症例

被 検 者： 45 才女子. 3 年前に右側聴神経腫瘍の脳外科的摘出術を受けた。

刺 激 頻 度: 4 回/秒

加算平均回数：後耳介反応の場合は200回 AP の湯合は400回

法は，頭頂部より記録される，潜時のおそい成分(V-potential) を指標とした大脑誘発電位聴力測定（通常 ER A と呼ばれている) である。しかしこの方法は，特に 乳幼児に応用するに際して, 反応域值判定の問題, 反応 出現性のばらつきの問題, 睡眠, 麻醉の反応におよぼす

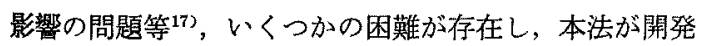
された当初に考えられたほど理想的なものでないことが わかってきた。最近, Yoshie 等 ${ }^{21)}$ (1967), Sohmer 等 ${ }^{19)}$ (1967), Portman 等 ${ }^{18)}$ (1968) が七トの蝸電図法を開発 して以来, 蝸電図法は，ERA よりすぐれた多くの点が あるため, めざましく発展をとげつつある.AP は, 末 梢聴覚柔 (蝸牛機能) の直接的な電気生理学的反応であ るため，他喾的聴力測定や難㯖の診断にとつては理想的 な指標と考えられる:
これ等の AP や大腷誘発電位とは別に， fast evoked response 又は, sonomotor response と呼ばれる (Bick ford 等 ${ }^{13}, 1964$. Mast ${ }^{13}$, 1965. Cody 等 ${ }^{3}$, 1964. Ruhm 等 ${ }^{191}$ ，1967）筋起源性と考えられる恥覚刺激性の誘発反 応が存在する。この反応は, 緒言で述べたように, 誘遒 部位によつて, 次の 3 種類に分けることができる.(1)後 頭部反応; 本反応性後頭隆起部より誘尊され, 頸筋の伸 展, 屈折により反応振幅が大きく影響を受ける事実より 筋性の反応と考えられている，反応の解剖学的経路とし $\checkmark$ Bickford 等 ${ }^{11}$ (1964) は, vestibulo-myogenic $の$ 経 路を推定した，この反応は検出域值が高く，他覚的聴力 測定の指標としては適切ではないと考えられる. (2)頭頂 部反応: 本反応は頭頂部上り誘導される短い潜時の反応 である.Mast ${ }^{13}$ (1965)によ机代，本反応の解剖学的経路 


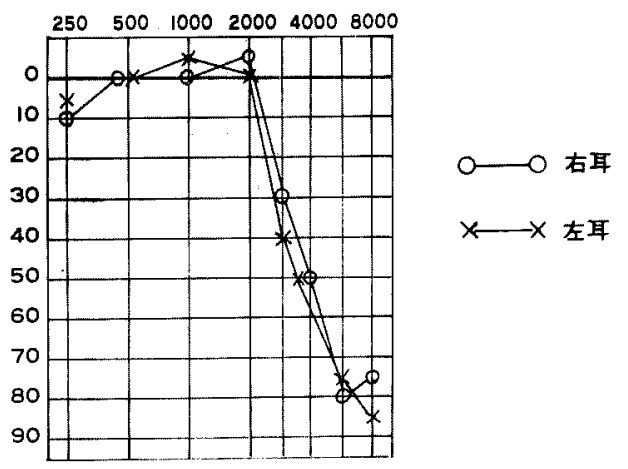

後耳介反応

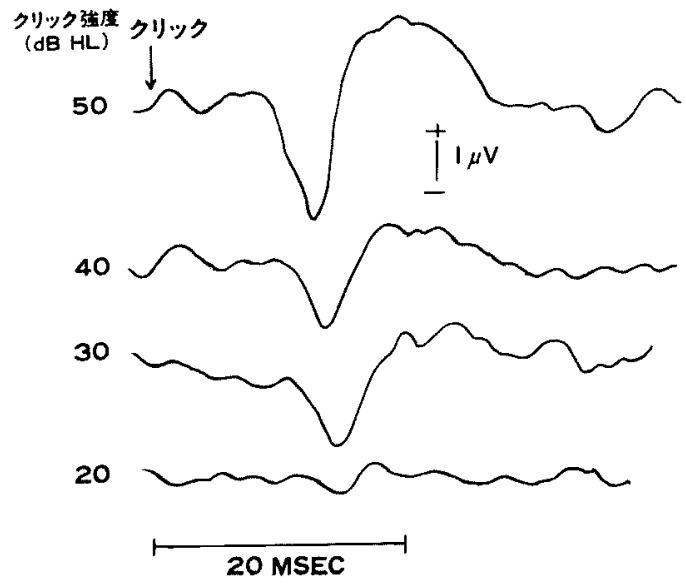

蝸牛神経活動電位

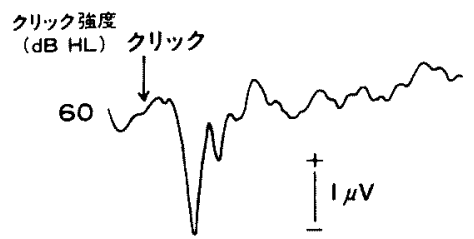

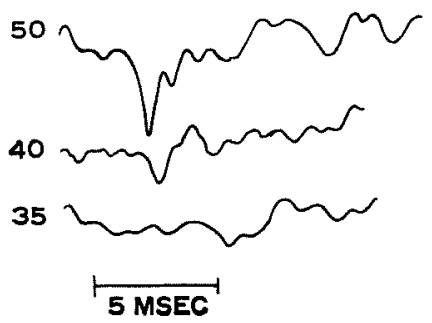

図一14 高音急壁型の聴力像を示寸内耳性難聴症例

被 検 者: 35才男子

刺激 頻 度: 4 回/秒

加算平均回数：後耳介反応の場合は200回 AP の場合は400回

は, cochleo-neurogenic であり笳群（前頭筋，側頭筋 等）の影響は些少であるが，恐らく muscle と brain の 合成反応であるらと述心ている（31後耳介反応；本反応 は後耳介部より誘導される. 反応の解剖学的経路として は, Cochleo-myogenic の経路が考えられ, 本研究で示 されたように反応城值が低く波形も明確篻純で，他敩的 聴力測定に応用するには最む適している。最近 Douek 等6) (1973) は, 後耳介反応（彼等は， crossed acoustic response と命名している) は，非常にすぐれた他覚的 聴力検査法の指標であると結論づけている，彼等は，刺 激強度が強、時忹筋性の反応が dominant だが，刺激が 弱くなると神経性の反応が dominant になると述心てい る. 類似の考え方を Ruhm 等 ${ }^{18)}$ (1967) む述べている. 彼等は，fast evoked response に二つの支配系統を想定
L (dual system), cochleo-neurogenic な反応は低い域 值を持ち，vestibulo-myogenic な反忘は高い域値をもつ ものとしている。これまで Douek 等 ${ }^{6}$ (1973) 以外の多 くの研究者がこの筋性誘発反応を他覚的聴力測定に応用 せんとして努力してきたが，反応の出現が筋の緊張状態 によつて非常に左右されるので, 他党的聴力検查の指標 とするには不安定すぎて実用化がすつかかいものと考え られてきた. しかし，われわれの今回の研究結果は, Douek 等の成績を支持するものである. すなわち本反 応は, きわめて簡単な操作で, 短時間内に，苦痛なく反 応の記録測定ができ，乳幼児の他覚的聴力測定にも利用 できる有効な指標であることが判明した．以下，本研究 の結果の重要項目について個々に考察を加えることにす る. 

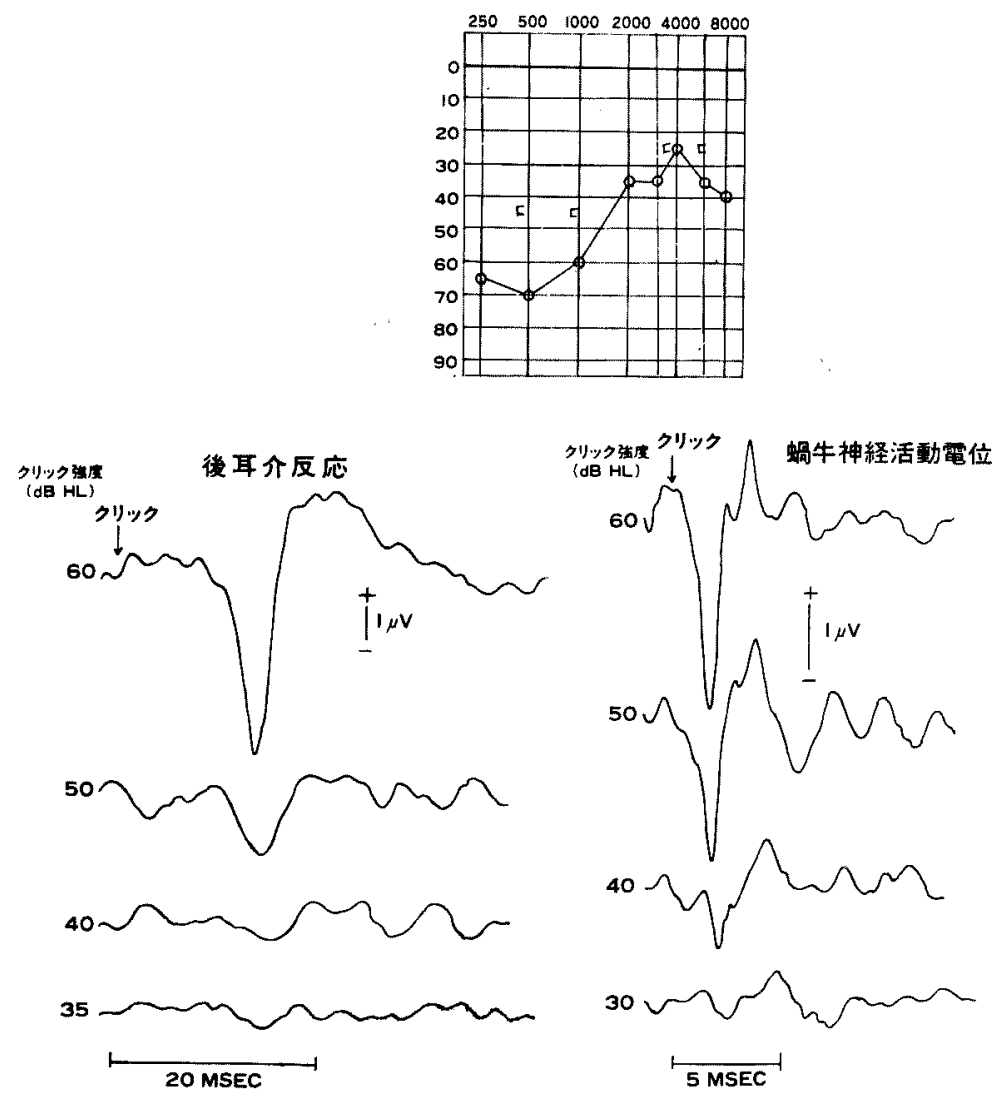

被検 者: 42 才男子

刺激 頻 度: 4 回/秒

加算平均回数：後耳介反応の場合は200回 AP の場合は400回

1）反応の解剖学的経路について，後耳介反応は，音響 刺激条件の変化 (刺激波形の変化等) によつて振幅, 域 值, 潜時が変化することや, 難聴によつて反応域值の上 昇が認められることから蝸牛を経由する反応であること が明白である. 更に，顔面神経麻疸の患者からは反応が 記録できないことから，顔面神経も介在していることが 考えられる.一方, Yoshie 等201(1969) の報告にもある よ5に，頭頸部の前後屈で反応振幅が著しく変化するこ と，歯をつよく咬みしめさせても同椂の変化を生ずるこ とも，反応が myogenic であることを示唆する。なお， 本反応の潜時は比較的短い点加ら (12 msec 17msec), 大 脳を介しているとは考えにくい 結論的にわれわれは， Douek 等の説を支持して, 反応の解剖学的径路として cochleo-myogenic の経路, 才なわち, 蝸牛一蝸牛神経— 脳幹部での未知の経路一顔面神経運動核一顔面神経後耳
介枝一後耳介管，の連鎖を想定したい

2) 後耳介反応の電気生理学的特徵. 後耳介反応山筋源 性反応であるから AP とは異なる順応現象を示すこと が本研究で判明した. Yoshie 等 ${ }^{20}$ (1969) も後耳介反 応の回復過程を観察し，AP のそれよりも本反応の回復 過程は延長することを認めている。 さらに後耳介反応 は，短音刺激の立ち上り時間を変化しても反応梳変化す ることが示されたが，変化の仕方は勿諭，AP のそれと は非常に異なるものであつた，例えば，後耳介反応は， 立ち上り時間 $50 \mathrm{msec}$ の短音刺激でも反応を検出乙得 た。一方， AP は， $5 \mathrm{msec} \sim 10 \mathrm{msec}$ の立ち上り時閒です でに反応検出は困難となることが一般的に知られてい $る^{99}$ ，後耳介反応が，おそい立ち上り時閒の刺激でも反 応する理由は, 本反応が後耳介管の粗大反応であるため AP の場合のように谖密なニューロンインパルスの時間 

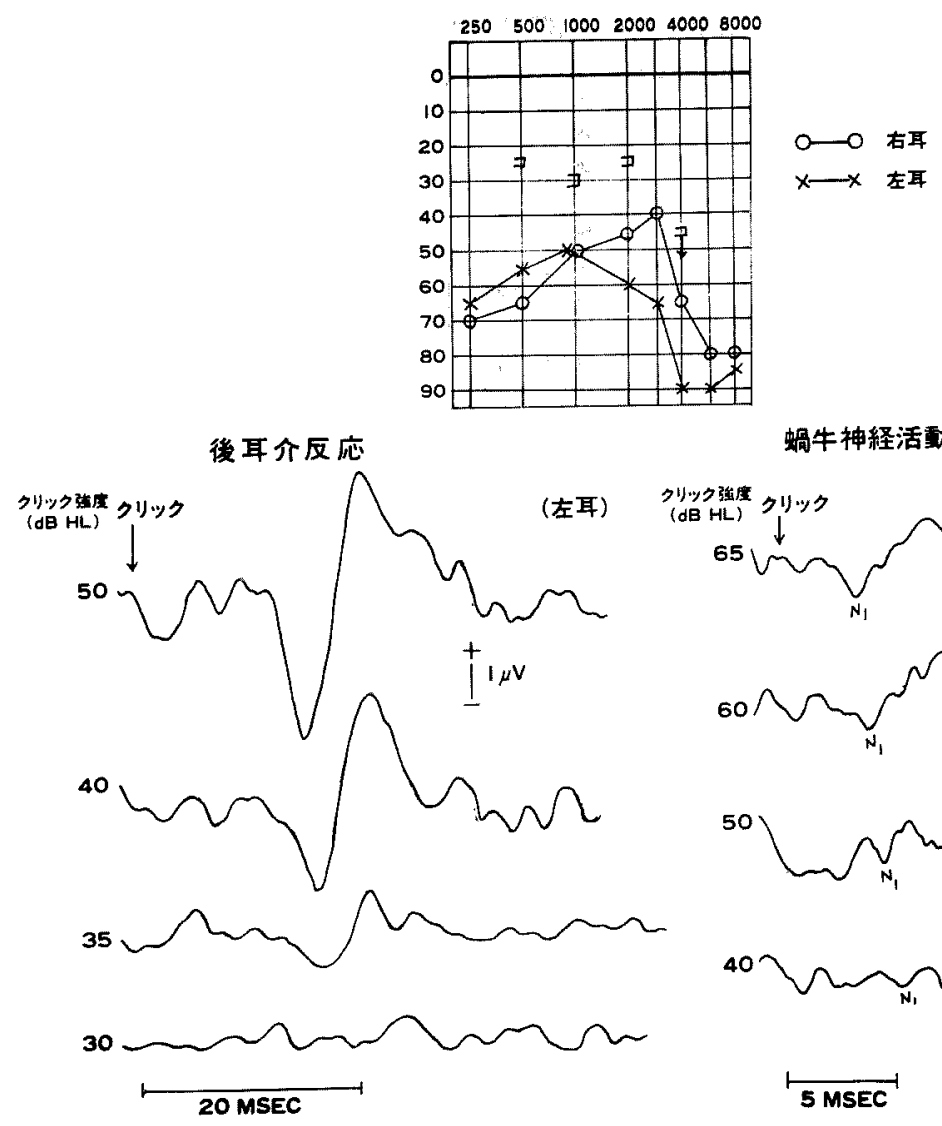

蝸牛神経活動電位

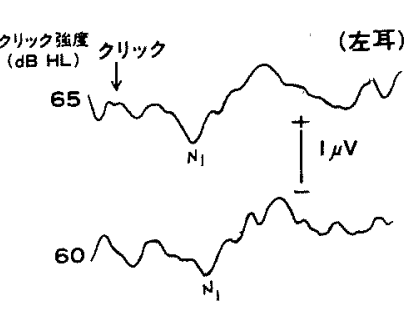

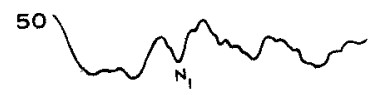

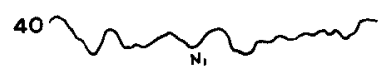

図一16 高度の聴力損失を示す混合性難聴症例

被 検 者：43才男子

刺 激 頻 度: 4 回/秒

加算平均回数：後耳介反応の場合は200回 AP の場合は400回

的同期を必要とせす，しかも反応の持続時閒が APより む非常に長いことからこの相違が説明できる.このこと は逆に, 後耳介反応が筋源性誘発粗大反応であることを 裏書きするものであるら。

後耳介反応は，AP と異なり，前述の長い立ち上り時 間の短音刺激のみならず，低周波の短音刺激でも反応を 記録することができた，その理由として，AP は基碟回 転に分布するニューロン群加らの同期性放電の集合電位

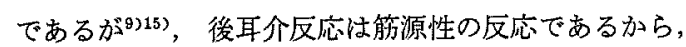
蝸牛神経レベルでの同期性は，かならずしも必要でな く, 前述の解剖学的経路の終着点の後耳介筋を time-locked に収縮させることができればよいためと考えられ る、したがつて，高音域に著明な聴力損失のある内耳性 難㯖でもAPと異なり，低音域からの反応(頭頂回転側の
反応）のみでも後耳介反応を記録することができたので ある.すなわち, 後耳介反応の出現には AP のよ5な蝸 牛神経レぶルでの時間的同期は必要でなく，少くとも， 基礎膜上の周波数領域にかかわりなく螖牛からの上行性 インパルスが後耳介筋に到達し, time-locked な収縮を 起さすに足るものであれば充分であると考えられる.

3）後耳介反応による他覚的聴力測定について，本反応 を他覚的聴力測定の指標として用いる場合, 最も問題に なるのは，反応出現の不安定さである，われわれの成績 でも正常耳で $22 \%$ 前後の記録不可能例が存在した. Goldstein $^{8)}$ (1967) 等は，安定な反応を得るために早い 刺激濆度を利用し，聴覚域值を判定しょうとする試みを 報告している，Douek 等 ${ }^{6)}$ (1973) は，反応の不安定さ を是正しよらとの試みとして，同時に両側の後耳介部か 
ら反応を記録し，両側からの反応を利用することを提唱 している．だが，実際問題として被検者の筋緊張の度合 いを一定に control することは至難の技である。したが つて反応振幅を判定の指標にすることは，あまり意味が ないと思われる。しかし，反応域值は比較的一致してい て個体差は比較的少く，域值も低、（特にクリック刺激 の場合は，約 $11 \mathrm{~dB}$ HL であつた）。この事実を利用し てわれわれは乳狕児の他覚的聴力測定に本反応を利用す るのである.

オージオグラム上の聴力像と後耳介反応域值オージオ グラムとの相関関係の解明は今後に残された重要課題で ある.しかし本研究ではクリック刺激だけでも，スクリ ーニング的聴力検査には充分役立つことが判明した．実 際, 臨床外来では, このようなスクリーニング的他覚的 聴力検查だけでも非常に役立つものである。

他覚的聴力測定の指標として，後耳介反応を利用する 場合の利点を列举すると(1)極めて単純な波形（陰一陽 2 相性)で検出，確認が容易である，(2)反応域值が低い （自覚域値纪近い）（3)記録手技が極めて容易である。 (4)反応の測定は短時間で完了する．(5)全く然痛性に記録 できる。(6)睡眠，麻醉時でも党醒時と同様の成績が得ら れる. (7)被検者の若千の体動は反応検出に影響を与えな 、等である，本反応記録の容易さは，われわれの報告 以外に，Douek等 ${ }^{6)}$ (1973) も述べているが，泇坚に， 覚醒時に遊ばせながら後耳介反応を記録することができ る位である。後耳介反応に上る他覚的聴力測定法は，脳 波の誘発反応聴力測定 (ERA) に勝るとも劣らない方法 であると考えられる。この方法は，日常外来で簡単に実 施できるので, 乳幼児のスクリーニングテスト的な他覚 的聴力測定法としては, 非常に有効なものといえよう。 現にわれわれは，外来で乳幼児聴力測定には，まず後耳 介反忘の反応城值測定を行ない，スクリーニング的な診 断情報を得て，次いで必要に応じて螖電図法を施行する ことにしている.

最後に，後耳介反応は，反応域值測定のみならず，脎 幹部病巣の他覚的鑑別診断に役立つ可能性の苏ることを 強調しておきたい，本反応はその解剖学的経路からみ て, 脳幹部を経由するので, 理論的に, 脳翰病䉓の局在 診断に利用できることが想定される，例えば，Douek

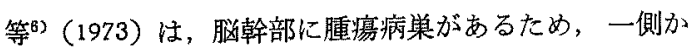
ら他側への脳幹交互性の情報伝達が遮断されて，他側の 後耳介反応が出現しない症例を報告している．脳幹部の 疾患と後耳介反応の出現の有無については，未だ検討寸
べき点が非常に多いので今後の研究の成果が期待され る。

\section{結語}

クリックおよび短音刺激を用いて，後耳介部より音響 性笳源性誘発電位を，正常耳22例，各種難聴耳 4 例加 記録した。なお，比較のため蝸牛神経活動電位 (AP) を 鼓室内誘導法により同時記録した，下記の成績を得た。

1） 反応波形は 2 相性 (陰一陽)である.

2）反応振幅は個体差が著しいが，潜時のそれは比校的 少ない

3）正常聴力耳で反応記録不可能例を 5 例認めた。

4）本反応の反応域值注低く，自覚域值化近い，クリッ ク刺激時の方方短音刺激時上り反応域值は低い

5）睡眠，麻酔時でも反応波形，反応域值は，覚醒時の それと変らない

6）本反応の順応現象はAPのそれとは異なる.

7）短音刺激時，刺激音の立ち上り時閒の変化とともに 本反応の振幅壮変化するが，AP とは変化の程度が異 なる。

8）難聴耳では反応域値の上昇を認める．特定の聴力像 を示す難㯖耳を除いて，後耳介反応の反応域值は， AP の反応域值とほほ一致する。

以上より後耳介反応は，他覚的聴力測定にとつて有効 な指標になり得るものと考えられ，更に，その記録測定 は，短洔間内儿苦痛なく簡単な操作で実施できるので， 特に乳幼坚の場合, スクリーニングテスト的な他覚的聴 力測定法として役立っものであるら。

\section{文献}

1) Bickford, R.G., Jacobson, J.L. and Cody, D.T. R.: Nature of average evoked potentials to sound and other stimuli in man. Amm. N. Y, Acad. Sci. $112 ; 204,1964$.

2) Borsani, S.J. and Blanchard, C.L..: Auditory evoked brain responses in man. Arch. Otolaryng. 80 ; 149, 1964.

3) Cody, D.T.R., Jacobson, J.L., Walker, J.C. and Bickford, R.G.: Average evoked myogenic and cortical pontentials to sound in man. Ann. Otol. 73 ; 763, 1964.

4) Davis, H.: Sonomotor reflexes: Myogenic evoked potentials. In the young deaf child: Identification and management (Ed: H. Davis). Acta. Otolaryng. (stockholm). Suppl. $206 ; 122,1965$. 
5) Davis, H.: Slow cortical responses evoked by acoutic stimuli. Acta. Otolaryng. 59; 179, 1965.

6) Douek, E., Gibson, W. and Humpheries, K.: The crossed acoustic response. J. Laryng. Otol. 87 ; 711 , 1973.

7) Goldstein, R.: Sonomotor reflexes: Myogenic evoked potentials. In the young deaf child: Identification and Management (Ed: H. Davis). Acta. Oto laryng. (Stockholm). suppl. $206 ; 122,1965$.

8) Goldstein, R. and Rodman, L.B.: Early components of averaged evoked responses to rapidly repeated auditory stimuli. J. Speech. Hearing. Res. 10 ; $697,1967$.

9) Gcldstein, M.H. and Nelson, Y-S, Kinag.: Synchrony of neural activity in electric responses evoked by transient acoustic stimuli. J.A.S.A. $30 ; 107,1958$. 10) Jacobson, J.L., Cody, D.T.R., Lambert, E.H. and Bickford, R.G.: Physiological properties of post-auricular responses (sonomotor) in man. Physiologist. $7 ; 767,1964$.

11) Kiang, N.Y., Christ, A.H., French, M.A. and Edward, A.G: Postauricular electric response to acoustic stimuli in humans. Quart. Progr. Rep. Res. Lab. Electonics. M.I.T. 68 ; 218, 1963.

12) Lowell, E.L.: Sonomotor reflexes: Myogenic evoked potentials. In the young deaf child: Identification and Management (Ed: H. Davis). Acta. Otolaryng (Stockholm). suppl. 206; 124, 1965.

13) Mast, T.: Short-latency human evolked responses to clicks. J. Appl. Physiol. $20 ; 725,1965$.

14) 大築淳一, 大橋徹, 竹山勇, 吉江信夫：後耳介区応 の臨床応用への検討 (第 2 報) Audiology Japan. 17 ; 549 (No. 5), 1974.

15) 大橋徹：感音系難耳(特にsensory neural defects) 飞 扣ける蝸牛神経活動電位, 日耳离。72；1269，1969.
16) Portman, M., Aran, J.M. and Le Bert, G.: Electrocochle' ogramme humain en dehors de toute intervention chirurgicale. Acta. Otolaryng. $65 ; 105,1968$.

17) Rapin, I., Schimmel, H. and Cohen, M.M.: Reliability in detecting the auditory evoked response (AER) for audiometry in sleeping subjects. Electroenceph. Clin. Neurophysiol. $32 ; 521,1972$.

18) Ruhm, H., Walker, E. and Flanigin, H.: Acoustically evoked potentials in man. Meditation of early components. Laryngoscope. 77 ; 806, 1967.

19) Sohmer, H. and Feinmesser, M.: Cochlear action potentials recorded from the external ear in man. Ann. Otol. $76 ; 427,1967$.

20) Yoshie, N. and Okudaira, T.: Myogenic evoked potential responses to clicks in man: Electrophysiological measurements of human auditory function (Ed: Suzuki, T.) Acta. Otolaryng. (Stockholm). suppl. $252 ; 89,1969$.

21) Yoshie, N., Ōhashi, T. and Suzuki, T.: Non-surgical recording of auditory nerve action potentials in man. Laryngoscope. $77 ; 76,1967$.

22) Yoshie, N. and Ōhashi, T.: Clinical use of cochlear nerve action potential responses in man for differential diagnosis of hearing losses: Electrophysiological measurements of human auditory function (Ed: Suzuki, T.) Acta. Otolaryng. suppl. $252 ; 71,1969$.

23) Yoshie, N.: Diagnostic significanse of the electrocochleogram in clinical audiometry. Audiology. 12 ; $504,1973$.

稳を終るにのぞみ、御校閲をいただきました信州大学

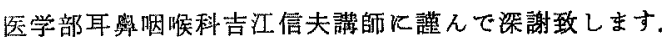

また，実験飞際し，御援助，御協力いただきました静岡 赤十字病院耳奥㸶喉科竹山勇部長, 皇晃医師並びに臨床 検查課，全原比良男課長飞感謝の意を表しょす。

（原稿受付 昭和50.4.28日急载） 